
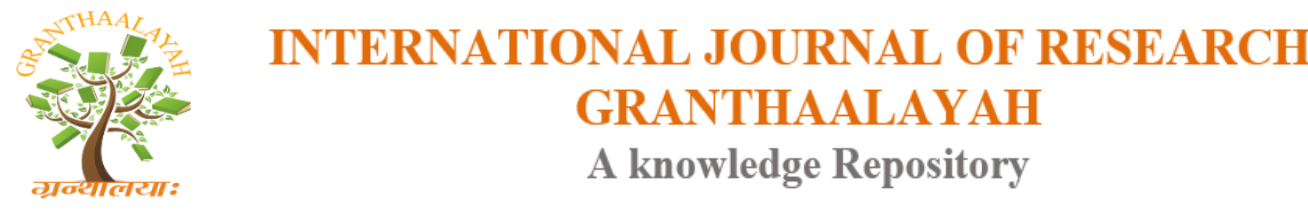

Management

\title{
AN ASSESSMENT BETWEEN ICT NETWORK COMPONENT AND ICT STORAGE ON JUDICIARY PERFORMANCE: CASE OF ELDORET LAW COURTS
}

\author{
Rose Mugeni Ndombi ${ }^{1}$, Dr Jenepher Munyua ${ }^{2}$, Dr Sanja Michael Mutong'wa ${ }^{3}$ \\ 1,2 The Catholic University of Eastern Africa, Eldoret, Kenya \\ ${ }^{3}$ Jaramogi Odinga Oginga University of Science and Technology, Kitale
}

\begin{abstract}
This research seeks to perform an Assessment between ICT Network Component and ICT Storage on Judiciary Performance in Eldoret Law Courts. The questions are: how does ICT Network component influence judiciary performance and does ICT storage influence judiciary performance in Eldoret law courts? The study adopted Correlational research design. The target group was Judges, Magistrates, ICT personnel and Advocates. A sample size of 272 was achieved from a target population of 899 employees in the Judiciary $<0.05$ was considered significant. Data will be analyzed by SPSS V 20; regression was used to test the hypotheses. Correlation and multiple regressions were used to measure: Effects. The $\mathrm{p}<0.05$ was considered statistically significant. The study findings indicated that there was a significant relationship between ICT Network component and judiciary performance $(\mathrm{p}=0.000)$; there was a significant relationship between ICT Data storage component and judiciary performance $(\mathrm{p}=0.000)$. The research conclusion indicate that use of ICT in the judiciary is vital in enhancing access to justice by creating an efficient court system and that access to justice involves making the court system accessible to all who require court services for instance judgments, it further established that ICT storage used by the MIS system in running transactions are effective, but require boosting. The study also concluded that all accessible points should be protected court information via internet. The study recommended that judiciary should adopt ICT initiatives after they have a specific plan in place to do so.
\end{abstract}

Keywords: ICT Network Component; ICT Storage and Judiciary Performance.

Cite This Article: Rose Mugeni Ndombi, Dr Jenepher Munyua, and Dr Sanja Michael Mutong'wa. (2018). “AN ASSESSMENT BETWEEN ICT NETWORK COMPONENT AND ICT STORAGE ON JUDICIARY PERFORMANCE: CASE OF ELDORET LAW COURTS.” International Journal of Research - Granthaalayah, 6(4), 345-350. 10.29121/granthaalayah.v6.i4.2018.1670.

\section{Introduction}

\subsection{Background}

According to Transparency International Kenya (2013), in Corruption Perceptions Index 2012, Kenya was ranked 139th out of 176 countries for corruption. However, the country scores 49 out 
of 100 in the 2010 Open Budget Index, which indicates that the government provides some information to the Judiciary, but this is insufficient for citizens to fully hold the government accountable for its management of Judiciary resources, even with ICT infrastructures use in Place (International Budget Partnership, 2010). Kenya has been struggling with corruption and mismanagement of Judiciary funds (Transparency International Kenya, 2013). With ICT infrastructures in place, Corruption in Kenya has drawn from Judiciary coffers over 600 million dollars in Goldenberg scandal and a further loss in Anglo leasing scandal (Transparency International Kenya, 2013). There are regular reports of tax evasion and high-level Government officials using their positions and influence or obtain tax exemptions for themselves or their relatives (Global Integrity, 2011).

Looking at the strategy in judiciary reforms introduced in the UK, results indicates that it was based on performance measurement through holding actors in the Judiciary individually accountable against pre-negotiated performance targets. At the same time in the United States of America (USA), performance measurement was spearheaded in 1993 by the then President Bill Clinton in a structure promoted as Performance Agreements (PAs) (Schiavo-Campo, 2008).

The principal recommendation to developing countries for automating their management systems is to adopt off the shelf ICT infrastructures. The recommendation to adopt ICT infrastructures goes beyond a strategy of automation.

Computerization and Information technology have played a major role in improving the quality and delivery of justice; improved timeliness, accuracy, efficiency, cost-effectiveness, competitiveness, transparency and accountability as major positive consequences of the use of information and communication technologies (ICT) infrastructure in courts (Fairchild,2006). However, the Judiciary continues to face a challenge of harnessing these ICT infrastructures in their attempt to adapt to the new economic and social trends of globalization (Malik, 2002).

The judiciary should carry out an assessment of systems within the judiciary and oversee the designing and implementation of court ICT management systems in the institution to ensure smooth flow of justice in the courts (Fairchild, 2006). In the western countries, court systems have been found to be manual in nature; the decisions used to be written even for cases related to mass litigation. The process used to be time consuming but ever since they embraced ICT, all the previous challenges have been eliminated (Bhattacharjee, 2012).

Most of these studies seem to suggest that ICT has only brought about positive change and has boosted the efficiency of our society while this is not a true notion. In Africa, many developing countries have not integrated ICT in their judiciary processes and still depend on the old paper system. This has slowed down the general judiciary process in most sub- Saharan countries, a good example being Somali (Allen, 2003).

Today, the Kenyan Judiciary is aware of the major role ICT plays in facilitating access to justice and has embarked on reform initiatives aimed at improving access to justice and enhancing transparency and accountability in the execution of its constitutional mandate. The judiciary startegic plan seeks to address the requirements of circular 02/09 which requires Civil and Judiciary service departments to develop plans to reduce expenditure on external consultants and 
become more self-sufficient in terms of ICT development, operations and management. Hence self sufficiency of courts service in maintaining the quality and progress it has so far achieved to date at a cost which represents value for money (State of the judiciary 2011).

Time, has now come for the judiciary to systematically measure the outputs that ICT interventions in terms of specific infrastructure have yielded in terms of performance that these investments and interventions have been made to enable judicial officers and staff to improve their productivity and performance in the courts. What remains to be determined, however, is how best to implement this technological change (Mutunga, 2012).

This paper therefore synthesized the guidelines and good practices in broad terms for using ICT tools in the Judiciary and focuses on the accessibility, cost-effectiveness, confidentiality, quality service delivery, timely justice, validation and management factors of ICT tools.

\section{Research Methodology}

\section{Research Design, Target Population, Research Instruments}

This study employed a cross-sectional descriptive survey. Surveys are a popular method of collecting primary data. Quantitative research methods were key to this study. Quantitative research was based on the measurement of quantity or amount, (Kothari, 2004). Target population done at the Eldoret law courts serves residents of Uasin Gishu County and its surrounding. It is categorized into three that is: the Eldoret High Court, Eldoret Chief Magistrate's Court and the County Court (Established from the Eldoret law courts of Uasin Gishu County which is categorized into three that is : the Eldoret High Court, Eldoret Chief Magistrate's Court and the County Court).The research targeted the following respondents; Judges, Magistrates, advocates and system operators. The target population was 899. Questionnaires were the main instruments of data collection for this study since it is the most appropriate tool to capture data which can best be obtained directly from the respondents (Morgan 1970). Closed ended questions helped to standardize and quantify responses from the Research. The open ended questions in the questionnaire ensured that an in-depth data that is detailed and explorative of all aspects of the variable or variables under study.

\section{Data Analysis}

The analysis used descriptive statistics both qualitative and quantitative in order to achieve the objectives of the study .The data was analyzed and presented in form of tables, frequencies and percentages. The study adopted both the qualitative and quantitative analysis in order to achieve the objective of the study.

\section{Correlation and Regression Analysis}

The established the relationship between the study variables. The study results on the relationship between ICT infrastructure and judiciary performance were as presented. This research also employed multiple regressions as a method of data analysis. In statistics Regression is a device used to model the relationship between a scalar dependent variable and an explanatory variable. 
This study used the multivariate regression model because multiple correlated dependent variables are predicted in this study. The data collected from the field was modeled using regression predictor functions. Multiple regression analysis technique was used to determine the effect of independent variables on the dependent variable, it was used to measures the relative influence of each independent variable based on its covariance dependent variable and was useful in forecasting.

Usually, it is most appropriate when both the independent and dependent variables are interval, though some social scientists also use regression on ordinal data.

Table 1:

\begin{tabular}{|c|c|c|c|}
\hline & & \multicolumn{2}{|c|}{ Correlations } \\
\hline & & $\begin{array}{c}\text { ICT } \\
\text { Network } \\
\text { component }\end{array}$ & $\begin{array}{l}\text { ICT Data } \\
\text { storage } \\
\text { component }\end{array}$ \\
\hline ICT & Pearson & 1 & \\
\hline Network & Correlation & & \\
\hline component & Sig. (2-tailed) & & \\
\hline $\begin{array}{l}\text { ICT Data } \\
\text { storage }\end{array}$ & $\begin{array}{l}\text { Pearson } \\
\text { Correlation }\end{array}$ & $.580^{* * *}$ & 1 \\
\hline component & Sig. (2-tailed) & 0.000 & \\
\hline ICT & Pearson & 0.407 & 0.104 \\
\hline Operating & Correlation & & \\
\hline system & Sig. (2-tailed) & 0.642 & 0.306 \\
\hline
\end{tabular}

The study results indicated that there was a significant relationship between ICT Network component and ICT Data storage component $(\mathrm{r}=0.580, \mathrm{p}=0.000)$. Pearson correlation coefficient of 0.580 showed a moderate positive correlation between ICT Network component and ICT Data storage component. There was a significant relationship between ICT Network component and Judiciary performance $(\mathrm{r}=0.679, \mathrm{p}=0.000)$. Pearson correlation coefficient of 0.679 showed a strong positive correlation between ICT Network component and judiciary performance. There was a significant relationship between ICT Data storage component and judiciary performance $(\mathrm{r}=0.618, \mathrm{p}=0.000)$.Pearson correlation coefficient of 0.618 showed a strong positive correlation between ICT Data storage component and judiciary performance.

Table 2:

\begin{tabular}{llrrrrr}
\hline \multicolumn{7}{c}{ Model Summary } \\
\hline Model & $\mathrm{R}$ & R Square & $\begin{array}{l}\text { Adjusted R } \\
\text { Square }\end{array}$ & $\begin{array}{l}\text { Std. Error of } \\
\text { the Estimate }\end{array}$ & F & Sig. \\
$\mathbf{1}$ & $.936^{\mathrm{a}}$ & 0.877 & 0.868 & 0.0868 & 99.676 & $0.000^{\mathrm{b}}$ \\
\hline
\end{tabular}

\section{ICT Data Storage Component and Judiciary Performance}

The study findings indicate that majority of the respondents were of the opinion that case information is easily accessed from computers. These findings are in agreement with findings by Raba (2009) who concluded that the use of ICT in the judiciary is necessary to enhance access to justice. This is because a significant number of the respondents applauded its use and regarded it as essential to enhance the performance of the judiciary. 
The level of exposure necessary to kick start change in the judiciary is quite basic. Most of the judiciary staff, though not adequately trained in ICT, has received some form of training that has brought an impact in the manner in which services are rendered. If they are adequately trained and provided with more of the ICT resources that are yet to be utilized effectively, then the performance will definitely improve.

Lastly, though ICT has enhanced equitable access to justice for Kenyans, the impact is not Satisfactory as a significant number is dissatisfied with its use. Notably, there are ICT resources that have not been fully utilized thus undermining the efforts by the judiciary to fully embrace ICT and enhance access to justice.

Table 3

\begin{tabular}{lrrrrr}
\hline \multicolumn{7}{c}{ Coefficients $^{\mathrm{a}}$} & & & \\
\hline Model & \multicolumn{2}{c}{$\begin{array}{l}\text { Unstandardized } \\
\text { Coefficients }\end{array}$} & $\begin{array}{l}\text { Standardized } \\
\text { Coefficients }\end{array}$ & & \\
& $\mathrm{B}$ & Std. Error & Beta & & \\
(Constant) & 0.369 & 0.224 & & 1.648 & 0.105 \\
ICT Network component & 0.263 & 0.024 & 0.534 & 10.744 & 0.000 \\
ICT Data storage & 0.17 & 0.026 & 0.319 & 6.604 & 0.000 \\
component & & & & &
\end{tabular}

Similar research by Mutunga (2011) also observed that database contains another set of key information maintained at a centralized database with a list of cases filed, and the respective judicial officer hearing the matter and the interim and final orders constantly documented, updated, disseminated, monitored and evaluated by purposely designated information communication technology specialists and legal researchers. The Case Management System (CMS) will be in use in all the courts in the judiciary. This will ensure that there are no back logs of cases.

\section{Conclusions}

Based on the study findings, the study made the following conclusions: The use of ICT in the judiciary is vital in enhancing access to justice by creating an efficient court system, it has been faced by various challenges that inhibit its efficiency. These include creation of a comprehensive ICT program that cuts across all the departments involved directly or indirectly with the judiciary including the lower courts.

\section{Recommendations}

The study focused on the influence of information communication technology infrastructure on judiciary performance in Eldoret Law courts, Kenya. The study recommends that similar study to be carried in other arms of government since arms of government are not the same. Further the study recommends that a study to be carried out on the comparison of sources of judicial performance in different regions and finally the study recommends another study on the relationship between judicial staff training and judicial performance 


\section{References}

[1] Allen, K., (2003). Law in the Making. Oxford: Clarendon.

[2] Benbasat,I., and Zmud,R., (1999).“Empirical research in information systems". The Practices of relevance. MIS Quarterly,23(1),3-16.

[3] Benbasat, I., Goldstein, D., K., Mead., M., (2007). The Case Research Strategy in Studies of Information Systems. MIS Quarterly, 11(3), 352-286.

[4] Belsely D., Kuh, E., and Welsch, R., (1980) Regression diagnostics: identifying influential data and sources of collinearity. NY: John Wiley and Sons.

[5] Bhattacharjee, S., (2012). Role of Information Technology in Quality of Judgment and Delivery. Journal of Science and IT management.

[6] Chestan, M., (2008). Nature of the Judicial Process. New Haven: Yale Univ. Press. Das, DeLone, W., H., \& McLean, E., R. ., (1992). Information Systems Success: The Quest for the Dependent Variable. Information Systems Research, 3 (1): 60 - 95.

[7] Delone, W., H., \& Mclean, E., R., (2003). The DeLone and McLean Model of Information Systems Success:A Ten-Year Update. Journal of Management Information Systems, 19(4), 9-30.

[8] DeLone, W., H., and McLean, E., R.., (2004).Measuring e-Commerce Success:

[9] Applying the DeLone \& McLean Information Systems Success Model, International Journal of Electronic Commerce, 9 (1): 31 - 47.

[10] Devaraj, S., Fan, M., \& Kohli, R., (2002). Antecedents of B2C Channel Satisfaction and Preference: Validating E-commerce Metrics. Information Systems Research, 13 (3):316 - 333.

[11] DFID (2003). Understanding and reforming public expenditure Management, Guidelines for Department for International Development. www.dfid.gov.uk/pubs/files/pfma- pem.pdf

[12] DFID (2003). Making it Work; "Implementing Effective Financial Information System in Bureaucracies in Developing countries". United Kingdom, Discussion paper No. 447, HHD, P 126.

\footnotetext{
*Corresponding author.

E-mail address: rose_ndombi89@gmail.com/jmunyua@yahoo.com/sanja_michael@yahoo.com
} 